Portland State University

PDXScholar

5-18-1973

\title{
Communication Barriers Between White Social Work Students and Black and Chicano Clients
}

\author{
Robert Hight \\ Portland State University \\ Joyce B. Smith \\ Portland State University \\ Evelyn F. Maxwell \\ Portland State University \\ Carol G. White \\ Portland State University
}

Follow this and additional works at: https://pdxscholar.library.pdx.edu/open_access_etds

Part of the Social Work Commons

Let us know how access to this document benefits you.

\section{Recommended Citation}

Hight, Robert; Smith, Joyce B.; Maxwell, Evelyn F.; and White, Carol G., "Communication Barriers Between White Social Work Students and Black and Chicano Clients" (1973). Dissertations and Theses. Paper 2548.

https://doi.org/10.15760/etd.2543

This Thesis is brought to you for free and open access. It has been accepted for inclusion in Dissertations and Theses by an authorized administrator of PDXScholar. Please contact us if we can make this document more accessible: pdxscholar@pdx.edu. 
TO THE OFFICE OF GRADUATE STUDIES:

The members of the Committee approve the practicum of Robert M. Hight, Evelyn F. Maxwell, Joyce B. Smith, and Carol G. White presented May 18, 1973.

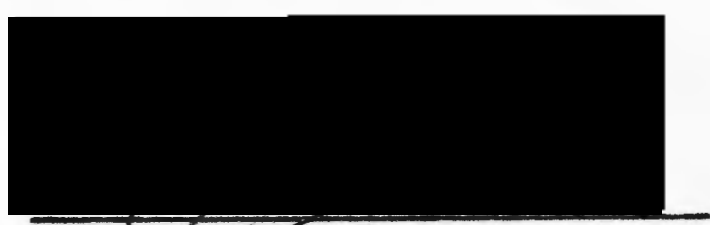

Adrian BontJe, Chairman

APPROVED:

Dr. Gordon Hearn, Dean of the School of Social Work May 18, 1973 


\title{
COMMUNICATION BARRIERS \\ BETWEEN WHITE SOCIAL WORK \\ STUDENTS AND BLACK \\ AND CHICANO CLIENTS
}

\begin{abstract}
by
Robert M. Hight Joyce B. Smith

Evelyn F. Maxwe11 Carol G. White
\end{abstract}

A report submitted in partial fulfillment of the requirements for the degree of

MASTER OF SOCIAL WORK

Portland State University

1973 
TABLE OF CONTENTS

\section{Page}

I INTRODUCTION....................... 1

II REVIEW OF LITERATURE................. 3

III METHODOLOGY....................... 24

IV ANALYSIS OF DATA................... 28

v IMPLICATIONS..................... 48

VI CONCLUSIONS....................... 54

VII APPENDICES :

A Questionnaire.................. 56

B Additional Statistics............ 63

C Non-white Faculty and Students at Portland State University School of Soclal Work Since 1962........

D Non-white pollcy goal statement...... 66

FOOTNOTES........................... 69

BIBLIOGRAPHY..................... 72 
Table I Use of Same Words but Different Frame of

Reference.

Table II Inadequate Skill in Other Language........

Table III Using Language Other Doesn't Onderstand...

Table IV Inadequate Knowledge of Other Cultures....

Table V Judging with Negative and/or Positive Expectations....................... 31

Table VI Student Experience with Proposed Barriers. 32

Table VII other Barriers..................... 34

Table VII Most Critical Barriers................ 36

Table IX Overcoming Barriers.................. 40

Appendix B $\quad \ldots \ldots \ldots \ldots \ldots \ldots \ldots \ldots \ldots \ldots \ldots \ldots \ldots \ldots \ldots \ldots \ldots . . \ldots$

Appendix C Table I........................... 64

Appendix C Table II........................... 65 
I INTRODUCTION 


\section{INTRODUCTION}

One of the central goals of social work education has been to enable the student to gain some understanding about the individual's life experiences, needs and abilities. However, we are concermed that schools of social work tend to avoid the subject of race per se, and its impact on particular clients and the worker client relationship.

As second year students at Portland State Univeraity School of Social Work, we have become increasingly aware of the effect of racial and cultural differences on communication. We have observed a lack of course content on commmication skills in general. In addition, we were concerned that the School of Social Work was not providing students with opportunities either in the classroom or in field experiences to enable them to understand differences and improve their cross cultural communication abilities. We thus decided to focus on this area as the subject for our practicum.

The potential range of communication barriers between people of different cultures is so broad that we arbitrarily limited our study. We decided, because of our interest in social work education to focus on communication between white social work students and black and chicano clients which represent the largest minority group in the United States. Our study deals with the issue of communication barriers between these groups. A questionnaire was devised and administered to students at the School of Social Work in order to determine their opinfons about communcation barriers and possible solutions to these problems. 
Because we were unable to measure the existence and extent of barriers present, we decided the opinion of Social Work students would provide us with the necessary information.

The paper is divided into three sections:

1. Review of iiterature--a rationale for chooging this area for study,

2. Methodology and analysis of data,

3. Implications and conclusions of research. 
II REVIEW OF LITERATURE 


\section{REVIEW OF THE LTTERATURE}

The concept of communication has been defined in numerous ways. Frank Dance in his article "The Concept of Conmunication" identified no less than ten ways of looking at this concept which he derived after an extensive review of the literature. Since the purpose of this research is not to develop yet another definition of communication, it seems appropriate for us to accept that communication is necessary for human beings and to agree that it is "meaningful, purposive behavior."

Communication, both verbal and non-verbal, is the main vehicle by which the profession of social work is carried forth and is therefore an essential area to be examined. Any education and training of professional social workers must focus upon and be concermed with the factors present within the communication process. It should also facilitate social workers' effectiveness within this process with the development of skills in communication.

Skill in communication is generally recognized to be important in order to function effectively as a social worker. Skill in communication can be defined as "the giving and receiving of Information, signals and messages both verbally and non-verbally, $n^{2}$ in such a way that both persons involved in the process understand as clearly as possible what is intended. The concept that effective communication involves the acquisition of skills in this process necessitates looking at what might be barriers to sklllful commuication as well as ways of overcoming such barriers.

Since the interview is considered fundamental to the profession of social work and is a smaller, less complex unit than 
small groups or comminities, examination of the interview and its purpose may give some ingight as to why communication akills are important as well as factors that are disuptive to the communication process within the interview situation. The skill in commuication referred to here is that which the social worker uses in "conscious interaction" within the interview situation. Because the interview is a specialized form of communication it is influenced by different variables. "When the caseworker and the client are of different racial groups, the factor of race becomes an important variable in the casework treatment process." 3

"A good interview represents both a verbal and a non-verbal interaction between two or more people working toward a common goal." There are specific attitudes on the part of the social worker which help to enhance the possibility of the client teling bis own story within the interview and taking appropriate action in relation to bis problems. These are: acceptance of the client as a person, respect for his rights, interest and concern, objectivity, empathy, recognition of the client's values and avoldance of imposing personal moral judgments. These attitudes are generally agreed upon as basic to effect a "helpful" position within the interview. Without these basic attitudes it seems impossible to establish the relationship necessary to accomplish any goals upon which the social worker and client may agree.

"If the relationship between worker and client is basic to the casework process then the success of the casework process depends in a large measure on the kind of relationship established-and emotional understanding is crucial to it." 5 
Thus, understanding and empathy are crucial ingredients for an effective interview. However, Alfred Kadushin states "but how can a white worker imagine what it is like for the black client to live day after day in a society that grudgingly, half-heartedly, and belatedly accords him self-respect, dignity and acceptance that are his right as a person, or, more often, refuses outright to grant them to him? ${ }^{6}$ The chicano client because of his minority status has had very different experiences from the white social worker and has also experienced discrimination from the white dominant culture.

Race is a crucial dimension in American culture and carries with it institutionalized roles and patterns of behavior. Both the black/chicano client and the white social worker have experienced this in their lives and have not been able to avoid it. "The casework relationship, by its very nature, is a product of the mutual perceptions of client and caseworker--perception based on what each has been taught to see... they cannot be divorced from each Individual's attitudes, beliefs and social norms."7 Regardless of what socio-economic group the white professional social worker may have come from, by affiliation and education he is now considered middle class. The minority cllent, despite his socioeconomic status, has been discriminated against and has no reason to trust or confide in a white person. Many who have studied this problem...generally concede that currently the racial barrier in the interview makes rapport and understanding more difficult than was previously imagined. ${ }^{8}$ This means that when the client 
and the social worker are of different races or ethnic groups, the ramifications of this difference mast be given more than passing recognition by the social worker.

However, social work has traditionally followed the "doctrine of color-blindness." 9 This doctrine declares the common humanity of all people regardless of their color or physical characteristics; each individual is equally human and each has the same basic potentials. Social workers have been correct in insisting and in viewing each client as an individual in his own right. But the doctrine of color blindness, intended to eliminate bias and prejudice, has created a tendency among social workers to deny the exiatence of differences arising out of membership in different racial and ethnic groups. Although social workers camot realistically deny the existence of these differences, they often feel constrained to deny or suppress any feelings they have as a result of these differences. These feelings that are denied or suppressed, will affect any relationship upon which they impinge, 1.e., the interview involving the white social worker and the black or chicano client.

White social workers have comonly ignored race in their work with black persons.... Perhaps the social work professionals must deny--for their own comfort--the profound effect of discrimination on the social-paychological functioning of black Americans." 10 Every person, and particularly the social worker concerned with social justice, wants to believe he is not prejudiced. By avoiding the topic of race that belief may be safeguarded. 
By adhering to the doctrine of color blindness the white social worker may inhibit the commuication process in several ways. One way is the lack of self-awareness necessary to maintain this doctrine. A second way is the lack of awareness and the inability to underatand and place in proper perspective the non-white person's experiences in attempting to survive in a racist society.

While the racial difference between the white social worker and the non-white client and its implications are important, often these implications are not dealt with either by social workers in general or within the interracial interview. "Through all the areas of interview literature a basic theme exists. It is that the black man, because of over three hundred years of destructive experience with the white man, enters the interview situation with a set of attitudes and behavior which, if not considered, will negatively affect rapport and the outcome of the relationship." 11 There is little in the literature to support that this statement is less true for the chicano client; there is only a variation on the main theme of racism.

In reviewing the literature relevant to our area of research, it soon became apparent that there is an enormous lack of material concerned specifically with communication barriers between the white social worker and black or chicano clients. Nothing was found dealing directly with the topic of the white social work student and black or chicano clients. It was thus necessary to focus upon literature concerned with the white professional social worker and the black or chicano client. This is even 
more startling if one examines oniy the issue of the white professional social worker and the chicano client. Only recently has social work literature begun to examine the chicano individual and the problems he faces in white racist America. "The literature is practically devoid of material on racism and its impact on Mexican Americans--a group consisting of ten million persons of Mexican descent.... Over $80 \%$ of Mexican Americans are found living in the cities and like blacks, are the objects of racial prejudice and discrimination, which are reflected in their median family income of $\$ 4,165$ and in their education--7.1 years of school years completed compared with 12.1 school years completed for Anglos and 9.0 for blacks." 12

Since chicanos face much of the same white racism confronting blacks in this country, it is reasonable to propose that large numbers in both groups are placed in the position of being in need of and seeking the services of a social agency, thereby coming into contact with social workers. "Although the largest number of poor people are white, a disproportionate percentage of the black population is poor. Hence the racial barrier between white worker and black client is frequently complicated further by class barrier--white middle class worker and black lower class client."13 Statistics reveal that chicanos suffer from similar disproportionate porerty. ${ }^{14}$ If a number of blacks and chicanos are in need of social services, and come face to face with a social worker (usually white) what then are some of the barriers and problems confronting these individuals. 
While the major barrier in the interracial interview is the racial difference between white social worker black or chicano client, this major barrier can be broken down into amaller components. We would now like to discuss some barriers to communication that we extrapolated from the literature dealing with the white social worker and the black or chicano client. These barriers were developed after careful consideration of numerous articles.

A communication barrier may be defined as any hindrance to the task of communication. "... it is undoubtedly valid to say that communication obstacles exist to some degree in every interview. Our goal...is...to become aware of our behavior in interviews, to see where we may be creating obstacles, and to try and reduce these as much as possible..."15 Certainly the communication barFiers presented here are valid and can operate within any interview situation interracial or otherwise. However, because the factor of race has such an impact in our society, these barriers may be seen to be operating more frequently and be more difficult to overcome within the interracial interview.

In reviewing the literature there seemed to be two major areas, language and culture. Both of these areas are interrelated; however, for the purposes of clarity and comprehension we sought to organize the material according to these two major areas, with subgroupings under each area according to our definition of these communication barriers. There are three sub-groupings under language and two under culture. 


\section{Language}

Same Words but Different Frame of Reference

White social worker students and black and chicano clients use words which are a product of their own experiences. Since white social work students and black and chicano clients have had different experiences, the words they use, while the same, will reflect different meanings. "The interviewer cannot take it for granted that he understands the meaning of all the words the client uses nor that he understands the emotional implications of a term; nor ia it safe to assume that the client fully understands the worker's standard English."16 The white worker and minority client may ascribe different meanings to words they both use. They may have very different ideas about the meaning of words such as love, hate, courage or cowardice. "The kinda of coding rules used by a communicator are determined by his subculture." 17 Bryant Wedge further elaborates upon this in his article, "Iransnational Commmication." He was particularly concerned how an individual's cultural background can influence the meanings evoked by symbols, words and gestures and the large variation possible within the cross-cultural comminication process. These meanings are often based on assumptions that are not overtly expressed and assume most persons operate on the same basic meanings. The danger of misinterpretation within the communication process of two people of different cultural experiences is great and may lead to a barrier in communication. ${ }^{18}$ Evidence 
that this particular barrier is operating within the interracial interview include: the look of incomprehension, the irrelevant response, or a kind of passive acceptance or denial. Inadeguate Sk111 in Other Language

While this is closely related to the above, it is somewhat different. A communioation barrier exists when the white social worker does not have an understanding of the client's indigenous language, i.e., Black Engliah or Spanish. For example, in the black idian of Chicago and elsewhere there are various words that refer to talking; rapping, shucking, jiving, running it down, griping, coping a plea, signifying and sounding. These terms refer to different kinds of verbal behavior. Whites have frequently assumed that blacks living in the ghetto, have difficulty verbally expressing themselves. However, "...studies of speech behavior in the ghetto suggests that blacks show great imaginativeness and skill with language. Thus, the worker has the obligation to learn the special language of the ghetto." 19

If the white social worker holds the misconception that blacks are non-verbal or have difficulty expressing themselves because he is not familiar with "Black English" this then creates a barrier to communication. It is important that the white social worker have knowledge of these language differences; however, a self-conscious effort to make use of such a vocabulary introduces a note of artificiality that defeats the purpose of the interview. Inaccurate use can cause the black client to be even 
more distruatful of the white social worker. Even if the use is accurate, this may be interpreted by the black client as being patronizing. "... when the Professional adopts the language of the Poor People, unless he can do so in a natural fashion, he runs the risk of being judged to be a phoney... This problem seems to be further complicated when a white Professional or Nonprofessional uses slang expressions that he considers to be peculiar to Negroes. Such usage of slang by white Professionals or Nonprofesaionals is evaluated in the same light as when a white person tells a Negro, 'Some of my best friends are Negroes.' The problem of doing casework with non-whites is not that non-whites are non-verbal, the problem is that white social workers have never learned to communicate with non-whites." 20

When we consider this communication barrier in relation to the chicano client, it becomes even more formidable. Language is one of the main barriers in working with non-English (or limited English) speaking chicanos. Aguilar cites a case example where, although the family spoke some English, it was not until a Spanish speaking social worker made contact with the family that the family could begin to make use of needed social services. 21

Faustine Knoll suggests in her article, "Casework Services for Mexican Americans," that working with chicano clients is not so different from other families. Nevertheless, "This client population does differ in respect to many specific cultural patterns. Language is the most obvious cultural characteristic specific to this client group..." 22 
Following two workshops on cultural relationships, Ramsey and Hodge learned from professionals in education, health, and social work, an important piece of information. Among those working with chicanos, they found that some spoke no Spanish and those few who did were not fluent enough to reach the deeper and more significant levels of comminication with their chicano clients. 23

\section{Using Language Other Doesn't Understand}

Social work jargon and technical words gained through advanced education may not be understood by the client. "It is a safe rule to use ordinary language that comes naturally. At the same time, one should avoid the use of technical or professional terms that may seem colorless or even meaningless to the elient. ${ }^{24}$ This is true with all clients regardless of racial background. In addition, however, the minority client may view the use of jargon and technical terms by the white social worker as a way of putting distance between them and as something to bide behind. "A Poor subject reported that the Professional used too many big words which led to an inability to understend the Professional. ...One subject might have interpreted the use of big words as an attempt to confuse while another subject might have interpreted the same behavior as an attempt by the Professional to show off his education." 25

Talbot Harding in his article, "Diagnosis and Treatment of Communication Failure," did not deal with the use of jargon with minority groups only, yet his statement, "as members of social 
welfare organizations, we must realize that, if we are to be understood..., we must communicate with the world on its terms-not on ours.... if social work... is to survive, we must be understood." 26

What good does it do for a social worker to be fluent in Spanish and knowledgeable of Black English if social work jargon is used to erect a barrier between social worker and minority client. Juan Ramos polnts to how social workers have "diagnosed parent-child relationships and extended family relationships by utilizing alien concepts and terminology (social workers, even those who speak Spanish, cannot translate certain psychological terms into Spanish).... ${ }^{27}$ and further emphasizes the uselessness of social work jargon in communicating with clients. CULTURE

Insdequate Knowledge of Other Cultures

Different cultures present different value systems which if not understood will present a barrier to communication. "The capacity to understand an individual in terms of his culture and the points and ways in which his culture and his response as an individual differs from one's own individual culture and one's unique way of responding is essential to any professional worker who attempts to help another... $n^{28}$

In the interracial interview there is a danger of misinterpreting the client's behavior. Therefore, before the social 
worker can be sure that the client is behaving inappropriately, he must have some knowledge and understanding of the client's cultural milieu.

Knowledge and understanding of the minority client's lifestyle will enable the white social worker to appreciate that much of the client's behavior is appropriate in his own culture and the adaptive qualities and the strengths implied by it. Quite often, however, the white social worker, perhaps without even being aware of it, may withdraw from intimate knowledge of the minority client's life and his experiences in a racist society, because placing himself in the position of his client even mentally is too painful. Since ouch knowledge is vital, in its absence the client suffers. 29 "Communication is an essential factor in establishing rapport and achieving a worker-client relationship through which change can occur. Ability of the client to ask for and accept help may be either weakened or enhanced, depending on the worker's sensitivity to cultural nuances and messages and his effectiveness or ineffectiveness in conveying his understanding." 30 .

Billingsley in bis article "Black Families and White Social Science," points out that black families have been mistreated in the literature or totally ignored and that this tends to perpetuate ignorance on the part of individuals in the helping professions such as social worker. He saw four tendencies in the treatment of black families in social science scholarship: 1. tendency to ignore black families altogether; 2 . when bleck families are considered to focus almost exclusively on the lowest income group; 
3. to ignore the majority of black stable families even among this lowest income group; 4. to view the black, low-income, unstable, problem-ridden family as the causal nexus for the difficulties their members experience in the wider society. 31

Ramsey and Hodge found that commmication problems between white professionals and chicanos goes beyond simple difference in language. They found the inability to understand each other to be rooted in diverse cultural background, different economic levels, and the separation by majortty and minority groupings. They felt that such differences in cultural backgrounds and experiences are so large, even if a common language did exist, it would be extremely difficult for the Anglo and chicano to really understand each other. This is especially true when attempting to communicate in areas of feelings, attitudes, and ideas. This was clearly seen when Anglo workers tried to communicate or interpret ideas ouch as the value of education, need to save for the future, or the desirability for preventive health practices. Juan Ramos in the editorial notes in Social Caseworks May 1971 "La Familia Chicana" explains. "Various social programs have disregarded and divided the family units and addressed themselves to children and youth and not to the parents (the youth could speak Engliah, the parents could not). They have attempted to transform chicano families into Anglo families thus dismupting useful processes (social workers knew what was good for the families); to diagnose parent-child relationships and extended family relationships by utilizing alien concepts and terminology 
(social workers, even those who speak Spanish, cannot translate certain peychological terms into Spanish; and to disrupt family and community processes conducive to the mental health of the community ("Bl oro del berrio" has no value when one's perspective is alien to the barrio)." 33

Judging With Nesative and/or Positive Expectations

When the white social worker is not able to perceive the individuality of the minority client but is influenced by stereotypes whether negative or positive, any judgment made will present a barrier to communication. "Even though it is possible to generalize some information about racial groups, social workers must be careful of this lest they fail to individualize a particular client.". 34

Social workers are repeatedly instructed to be non-judgmental, and hopefully, are able to obtain a certain amount of objectivity. However, because of the nature of recism in this country, every white social worker will have feelings and orientations about the matter of race. The individual white social worker may deal with these feelings about race in various ways within the interview process. Some may over-simplify the minority client's problems and attribute certain behavior to racial or ethnic group differences that should be ascribed to personel malfunctioning. Much of which is considered personal malfunctioning is a result of being in the minority in white America. However, when the white social worker diamisses behavior that is keeping the minority client and/or his family from doing as well as he can under the circumstances 
as "natural" or indicative of their minority culture, then that social worker is not fulfilling his obligation to the client. To the extent that some part of the minority client's life can change and become more satisfactory to himself and his family, something giconificant has been accomplished. Very often these same social worker may be mistaken by applying their understanding of cultural differences to the individual situation.

The social work profession has used terms such as "multiproblem, non-verbal, present-oriented, and culturally deprived ${ }^{\text {. }} 35$ again and again in social work literature and case recordings in reference to minority clients. Such terminology has to have some effect on how the white social worker will perceive the minority client. Current cliches such as these can be as handicapping to true understanding as were past stereotypes.

Michele Seligman, in the abstract of her Master's Thesis, "The Interracial Casework Relationship," found that white social workers felt they could relate easily to the Negro client, while they seemed more aware of possible difficulties they might have relating to their white clients. Race did influence white social workers in their choice of treatment modality for the client. Preconceptions about Negro clients seemed to influence the choice of family therapy for the white client and individual interviews for the Negro client. 36 Since this is an abstract one can only speculate concerning the meaning of her findings. It seems apparent that the social workers in this study were not aware 
that they were judging and using expectations toward the black client that differed from those applied toward the white client. They certainly were not perceptive of how they helped maintain the facade that many blacks have had to assume when in contact with whites. This study, along with several others, tends to support the theory that white social workers, as products of their culture, have often applied negative and prejudicial generalizations to blacks.

Robert Archibald, in his Ph.D. Thesis, "Cross-Cultural Communication: An Intrapersonal Perspective," points out that "...the many recent depictions of non-white cultures in the United States, especially by the mass media, have created numerous stereotypes regarding these oultures. Certain generalizations such as the matriarchal nature of the average Negro family may indeed be fact or myth. Stereotypic reactions have, however, appeared to make them fact. 37

Ramsey and Hodge agree with this in their findings. "We tend to stereotype all individuals with different cultural backgrounds rather than attempting to know them individually as people. 38

They also found, and this is supported by other articles, that the Anglos participating in the workshops felt that chicano parents felt little desire for their children to excell in school, that they did not delay gratification, and that their concept of time (time walks for the chicano) caused the professional considerable difficulty in working with chicanos. 
Barbara Shannon in her article, "Implications of White Raciam for Social Work Practice," states that "the white practitioner himself must get away from the martyr syndrome in relation to his interaction with blacks. He must stop considering himself someone special because of his interracial associations." 39

She further states that the white social worker mast be aware of the individual minority client's adaptive system. Because a black client seems amiable to the white worker, does not necessarily mean he is well adjusted. This goes along with comments made by several authors that white social workers tend to relate only to the "responsible Negroes"--those who agree to behave white and think white. If a black person deviates from this expectation, he immediately tends to be thrust into the role of a militant.

Another writer points out that the white social worker, in order to either make restitution for his felt or suspected raciam, or in order to demonstrate that he is not prejudiced, may oversimplify the client's problems." "The worker who feels suilty about his own racial and class identity in the presence of a Negro client may discover that he wishes to prove to the client that he is different from other whites... he may convey his agreement when the client expresses hostility toward whites, perhaps by encouraging him to elaborate on these feelings when it is not relevant to the course of therapy." 41 
Benjamin in his book, The Helping Interview, describes judging as a defense mechanism used by social workers in order to rationalize our behavior with certsin clients rather than coming to grips with our feelings about that client. "We judge the interviewee to be 'uncooperative,... asgresgive, submissive...' Consequently, we see him as auch, and more often than not, he will tend to see himself as such... May he not be acting this way because of us--because his perception of us or his reaction to our perception of him?" 42 He is not talking about minority clients per se, yet his comments seem relevant since most whites do tend to stereotype minority group members and white social workers are no exception from the total white population. "Culturally, white social workers, as part of a racist environment, have incorporated the society's negative stereotypes about blacks.... 43

Although the barriers mentioned are present in many helping relationshipa, they are heightened in the interracial contact because of the institutionalized racial attitudes in America. What is important is that racial differences do have an impact on the communication process within the interview. It is not enough for the white social worker to make statements such as, "I treat all clients the same, it makes no difference if the client is black, chicano, or white and I'm not prejudiced," without further reflection. Most authors agree "It is both incorrect and clinically unsound to argue that the dynamics of the casework process are not 
affected by the worker's race. Both the worker's and the client's responses to it...can stimulate or impede the establishment of a sound casework relationship. " 44

The social worker, in an effort to treat all clients equally and fairly, may conceal from himself the difference in his feelings toward different persons. Because he is not aware of these feelings, the social worker does not have conscious control of their expression. If these feelings are strong enough, they may find expression in ways that the social worker is not aware of and influence the interview in a way that the social worker does not anticipate or understand.

Almost without exception, the articles reviewed stated that the wite social worker must, in some way, let the minority client know that their racial or ethnic difference and related feelings can be discussed openly. Frequently this means that the white social worker must be willing to introduce this topic as many minority clients will not do so directly. Andrew Cury in his previously mentioned article, cites examplea of openly responding to the clients' negative feelings and comments about the worker being of a different race or ethnic group rather than glossing over or completely ignoring auch comments. He felt that such a procedure left open for the client the opportunity to discuss this area as well as functioning to facilitate an ongoing relationship and allowing the issue of racial or ethnic differences to be brought up as needed. 
Too often white social workers avoid doing this because it does provoke a certain amount of anxiety within the worker. It is safer to avoid dealing openly and directly with racial or ethnic differences. In order to understand why open communication about race is important, an appreciation of the life experience of the minority person with whites, as well as the attitudes of many minority persons toward social work is necessary. 45

We must be willing to abandon the doctrine of color blindness if we are to free ourselves and move forward in pursuing equality and social justice for all clients and most especially minority clients. This process must begin on an individual level and must be initiated in graduate education for social workers if it has not begun before that time. 
III METHODOLOGY 


\section{METHODOLOGY}

The purpose of this study was to determine what social work students see as barriers to communication between white social work students and black and chicano clients, and ways they see of overcoming these barriers. We had originally planned to limit our study to attitudes of white students but later decided to expand it to include non-whites as well. We thought the opinions of these two groups might differ as to how they perceived the importance of certain communication barriers.

Since we wanted student's opinions regarding communication barriers, we devised an opinion questionnaire. We structured the responses to the questionnaire by utilizing multiple choice type questions. We did this so we could readily record, categorize, and evaluate the results. The only open-ended questions were asked for student input for additional communication barriers, ways to overcome them, and comments regarding the questionnaire. The questionnaire was then administered to students by their methods class instructors. The ingtructor's task was merely to hand the questionnaires out and to retrieve them.

The questionnaire (see Appendix A) was divided into seven parts. The first part was an introductory statement. Here we proposed a definition for communication, the recognition that communication skills are important to social work practice and the puxpose of our study.

The second part asked for general information about the student answering the questionnaire. Here we asked students to indicate 
personal data such as age, sex, etc. After analyzing the data, only the category of ethnic background showed a significant effect on responses.

The third part of the questionnaire proposed five communication barriers. Our Review of the Literature shows many potential barriers, not oniy between whites and blacks/chicanos, but also between people in general. Our proposed barriers were placed into two general categories: language and culture. The first three barriers concerned language usage and cultural influence was represented by the last two barriers. (See Appendix A) We asked students to indicate their opinion as to the extent that these barriers block communication. In addition, we asked whether their answer was based on experience as we wanted to determine whether social work students have encountered these barriers. Because people from black and chicano backgrounds have unique characteristics, we decided to separate them rather than asking respondents to make a judgment about the two groups together.

In part IV, section $A$ and $B$, we asked if students felt other communication barriers exist, and if so, to name other significant ones. We did this so respondents would have the chance to make additions to our list. In section C, we asked the respondents to name what they felt to be the most critical barriers to communication. We wanted them to consider both the barriers we had proposed and the barriers they had proposed. 
Part V concerned ways to overcome the communication barriers. First we asked if the School of Social Work should include in its program ways for students to overcome communication barriers. We then asked whether students felt the School was providing them with experience that would help overcome these barriers. We included this question as it relates to our section on the School of Social Work program regarding non-whites.

Section C proposed five ways that the School of Social Work might use to help students overcome communication barriers. Our research brought up a number of possible ways to accomplish this. We chose from these a variety of ways which include both didactic and experiential learning. The first two ways were the traditional course work approach. The third way proposed was field experience with black and chicano clients, emphasizing communication skills. The fourth way of overcoming barriers was a live-in experience with black or chicanos, not a traditionally sanctioned learning situation. The final way we proposed was to admit more blacks and chicanos in the School of Social Work.

Taking these proposed ways to overcome barmiers, we asked respondents to rank how effective they felt they were on a scale of 1 (not effective), to 6 (very effective). Section $D$ of part $V$ asked reapondents to add to our ways of overcoming communication barriers. We were interested in finding out whether they felt there are other ways and to indicate the ones they were thinking of. In section $E$ we asked students to check the priority they would give the task of overcoming communication barriers. 
Part VI asked students how many black/chicano clients they have had as social work atudents, and how many have they had prior to enrolling at School.

Part VII provided students a chance to state any concerns or comments regarding the questionnaire.

Out of a potential 160 first and second year students, we received a total of 108 questionnaires back. Our population was eight-gix whites and twenty-two non-whites. 
IV ANALYSIS OF DATA 
ANALYSIS OF DATA

Part 111, sections A, B, C, D, and E, proposes barriers to communication (see Appendix A for explanation of each barrier). In some cases, respondents answered the question under the heading, "black client" and did not complete the section, "chicano client," or vice versa. In some cases, respondents chose not to respond to a barrier at all. Thus the number of responses varies with each proposed barrier.

Section A, Use of Same Words but Different Frame of Reference.

The following chart showg the percentages of white and nonwhites who see the above proposed barrier as blocking communication wen working with black and chicano clients respectively.

\section{TABLE I.}

Use of Same Words but Different Frame of Referemce

\section{DEGREE}

BLACK CLIEAN

CHICANO CLIENT

white non-white

white non-white

$\begin{array}{lllll}\text { no or little } & 23 \% & 13.5 \% & 17.5 \% & 10 \% \\ \text { medium } & 59 \% & 32 \% & 60 \% & 35 \% \\ \text { high } & 17 \% & 41 \% & 22.5 \% & 35 \% \\ \text { very high } & 1 \% & 13.5 \% & 0 \% & 20 \%\end{array}$

White students tended to see this as a relatively minor barrier to communication between themselves and both blacks and chicano clients. A large percentage checked either none (23\% for blacks and $17.5 \%$ for chicanos) or medium (59\% for blacks and $60 \%$ for chicanos). 
The non-white students, on the other hand, felt that it hindered comminication to a greater extent than the white students. Non-white responses divided more eveniy when considering the barrier between whites and chicanos. While $35 \%$ of the nonwhite population felt it is a medium barrier and $35 \%$ of the nonwhite population felt it is a high barrier, $20 \%$ of the non-whites felt it is very high in terms of hindering commmication. This is significant considering that none of the whites felt this barrier to be very high.

Section B Inadequate Skd1I in Other Language

TABLE II

Inadequate Skill in Other Language

\begin{tabular}{lcccc}
\hline DEGREE & \multicolumn{2}{c}{$\begin{array}{c}\text { BLACK CLIENT } \\
\text { white }\end{array}$} & \multicolumn{2}{c}{ CHICANO CLIENT } \\
\hline no or little & $22.5 \%$ & $14.5 \%$ & $11.5 \%$ & $11.5 \%$ \\
medium & $45 \%$ & $28.5 \%$ & $30 \%$ & $27.5 \%$ \\
high & $25.5 \%$ & $47.5 \%$ & $37.5 \%$ & $44.5 \%$ \\
verr hich & 78 & $9.5 \%$ & $21 \%$ & $16.5 \%$ \\
\hline
\end{tabular}

Most wites and non-whites felt that the degree to which this was a barrier to commication is either medium or high between white students and black clients. This might indicate that students recognize that Black English exists and can be a barrier to communication, but is not seen as an extreme barrier. Responses regarding chicano clients show that wite students 
recognize potential difficulties when Spanish is introduced as a factor. $21 \%$ of the whites indicated that this is a very bigh barrier while $16.5 \%$ of the non-whites saw it as such.

Section C Using Language Other Doegn't Undergtand

TABIE III

Using Language Other Doesn't Understand

\begin{tabular}{llclc}
\hline DEORES & \multicolumn{2}{c}{$\begin{array}{c}\text { BLACK CLIENT } \\
\text { white non-white }\end{array}$} & \multicolumn{2}{c}{$\begin{array}{c}\text { CHICANO CLIENT } \\
\text { wite }\end{array}$} \\
\hline non-whito
\end{tabular}

The responses to this barrier were fairly evenly distributed between all four degrees on the scale. More responses fall into "very high" and "high" than the previous commication barriers. The non-whites were inclined to see this as a high barrier (59\%), and a very amall percentage feeling that it produces no or little difficulty (4.5\%). These result might indicate that most respondents are already aware of the importance of using words which can be understood by another or it could indicate that respondents feel that most commication is done through verbal rather than non-verbal means. 
Section D Insdequate Inowledse of Other Cultures

TABLE IV

Inadequate Inowledse of Other Cultures

\begin{tabular}{llllc}
\hline DEGREE & \multicolumn{2}{c}{$\begin{array}{c}\text { BLACK CLIENT } \\
\text { mite }\end{array}$} & \multicolumn{2}{c}{$\begin{array}{c}\text { CHICANO CLIENT } \\
\text { nonite non-white }\end{array}$} \\
\hline no or little & $10.5 \%$ & $0 \%$ & $10 \%$ & $5 \%$ \\
medium & $18 \%$ & $13.5 \%$ & $19 \%$ & $10 \%$ \\
high & $46 \%$ & $54.5 \%$ & $44 \%$ & $55 \%$ \\
vers high & $25.5 \%$ & 325 & $27 \%$ & $30 \%$ \\
\hline
\end{tabular}

Respondents felt that this is a significant barrier. A large majority of both whites (72.5\%), and non-wites (86.5\%) checked that it was either high or very high between white students and both black clients and chicano clients. More nonwhites felt it functions as a barrier to a higher extent than whites; however, none of the non-white students saw it as being "none or little," as compared to $10 \%$ of the whites feeling this way. This might indicate that soclal work atudents recognize the importance of one's culture in working with clients.

Section E Judging with Nesative and/or Poeitive Expectations TABLE V Judsing with Nerative and/or Positive Expectations

\begin{tabular}{llcccc}
\hline DE:OREE & \multicolumn{2}{c}{$\begin{array}{c}\text { BLACK CLIEWT } \\
\text { white non-white }\end{array}$} & $\begin{array}{c}\text { CHICANO CLIENT } \\
\text { vite non-white }\end{array}$ \\
\hline no or 11ttle & $13 \%$ & $9.5 \%$ & $7.5 \%$ & $5 \%$ \\
medium & $33 \%$ & $14.5 \%$ & $30 \%$ & $5 \%$ \\
high & $47 \%$ & $57 \%$ & $52.5 \%$ & $60 \%$ \\
verr high & $7 \%$ & $19 \%$ & $10 \%$ & $30 \%$ \\
\hline
\end{tabular}


Non-white respondents saw this proposed barrier as a greater hindrance to communication than did white students. Their answers predominantly fell into either the high or very high categories as opposed to the white students which were more in the medium to high range. Possibly this reflects the fact that non-whites may have been subjected, during their lives, to stereotyping which they were acutely aware of, whereas whites are perhaps not so conscious of it because they are not subjected to it as overtly as non-whites.

After each respondent had marked the degree of a proposed communication barrier, we asked him to indicate if his response was based on personal experience with a black or chicano person.

The following chart shows the percentages of students who have had such experience in regard to each proposed barrier.

\section{TABLE VI}

Student Experience with Proposed Barriers

BARRIER

A. Use of same words...

blacks

chicanos

B. Inadequate skill...

blacks

chicanos

C. Using different language...

blacks

chicanos

D. Inadequate knowledge of other culture...

blacks

chicanos STUDRISS HAVIRT PERSOAAL EXPERTENCE white non-white

73.58

598

$57 \cdot 5 \%$

$60 \%$

$61 \%$

$57 \%$

$54 \%$

$31 \%$

$57 \%$

$54.5 \%$

$44 \%$

$45.5 \%$ 
E. Judging....

$$
\text { white }
$$

non-wite

\begin{tabular}{lll} 
blacks & $59 \%$ & $76 \%$ \\
chleanos & $46 \%$ & $60 \%$ \\
\hline
\end{tabular}

Our reaulte indicate that there is a difference between the way whites and non-whites think about the proposed barriers. A greater percentage of non-whites see the barriers we have proposed as being more significant and hindering communication to a greater extent than do whites. This may reflect the fact that non-whites have been in a similar position as blacks and chicano clients in terms of the dominant culture, having to learn a new language and to endure stereotypes. White students, on the other hand, may accept the way things are and never consider the burden it places on an individual who has not had the advantage of being white in a wite, middle class society.

\section{PART IV}

The purpose of part IV was to determine if students felt there are other barriers to communication, and to decide among all proposed barriers which ones are the most critical.

Section A. De you feel that there are other commuiation barriers between white sociel work students and black and chicano clients other than the ones stated above?

Again, non-whites felt more strongly that communication barriers exist than do whites. (57\% of the non-whites responded yes as opposed to $42 \%$ for whites.) Also, a lesser percent of the non-whites responded no and don't know (4.5\%), as opposed to $(8.4 \%)$ for white 
students. Both groups, however, did show a significant number of people who indicated that we did not cover all key barriers.

\section{Section B If Yes, Please State Others Which You See As Signifioant}

TABLE VII

\begin{tabular}{ll} 
& OTHER BARRIERS \\
\hline Other Barriers & $29 \%$ \\
\hline Black and chicano rejection of whites & $21 \%$ \\
Perceived self identity & $16 \%$ \\
Others & $16 \%$ \\
Institutionalized racism & $13 \%$ \\
Lack of degire to commicate & $5 \%$
\end{tabular}

Forty-seven students answered this question giving a totel of seventy-two responses. We asked for additional barriers to the ones already listed in the questionnaire, but over half (40), of the responses restated or paraphrased the given barriers. Possible explanations for this might include not reading the directions, or a need to put a concept in one's own words, and in one's own style.

The remaining thirty-two responses were grouped into the following six categories (from highest to lowest rate of response):

1. Black and chicano rejection of or bias againgt whites.

These responses indicated that commuication was hindered by the non-whites' negative attitude, distrust, and stereotyped perception of white social workers. This is a failure to see individual differences and the negative effect this may have on 
communication.

\section{Bnotionality of encounter}

Respondents stated that a charged emotional atwosphere prevailed during the interaction of a white social work student, and a black or chicano client. Both social worker and client were sald to have feelings of anxiety and defongiveness.

\section{Perceived self identity and role}

Here it was indicated that social and professional role playing was a major barrier to communication. Both white and non-white were seen as needing to preserve and protect their self-identity which resulted in a rigidity of personality and an inability to see the person behind the role or mask.

\section{Institutionalized and individual racism}

Racism was seen as a barrier to communication. The respondents saw raciom as represented by white middle class institutions, and by the "agstem" with its "white supremist doctrines."

\section{Leck of interest or desire to comminicate}

Here was expressed the idea that opposites repell each other, that neither white nor non-white would take a chance to try to commonicate with one another.

6. Other

Responses that occurred only once or twice were grouped into one category and included proposed commmication barriers of the 
following types: Use of interpreter, physical differences between client and worker, unconscious barriers, ignoring nonverbal behavior, and certain methods of communtcating, i.e., letters, case conferences, etc.

\section{Section C. In Your Opinton, What Do You Think Are the Yost Critical Barriers to Communication (Include Both our Proposed Barriers and Yours).}

TABLE VIII

MOST CRTTICAL BARRIERS

Nost Critical Barriers

"g" Judging $24.5 \%$

One's value and culture $19.5 \%$

"D" Inadequate knowledge $11.0 \%$

Lack of Understanding 9.58

"C" Language other doesn't understand 9.08

"B" Inadequate akill $7.5 \%$

Other $6.5 \%$

"A" Same words, different frame of reference $5.5 \%$

Lack of trust $4.0 \%$

Unwilling to rigk self-exposure $3.5 \%$

This question asked the respondents to cite what they felt were the most critical barriers to communication. They could draw from the proposed barriers in the questionnaire or from their 
own experiences and ideas. Ninety-eight people responded to this question with a total of 155 separate responses.

It is interesting to note that the proposed barrier that elicited the most responses was the last one listed in the questionnaire (E), and the proposed barrier that received the least responses was (A), at the beginning of the questionnaire with the other barriers spaced progressively and in order in between.

Some possible explanations might be that 1. This occurred by chance. 2. We had biased the questionnaire by putting the most obvious barrier last. 3. Respondents took time to understand and get acquainted with questionnaire so they were conservative with their initial responses.

There were sixty-six responses to this question that listed barriers other than the ones provided by the questionnaire. From highest to lowest rate of response we have:

\section{One's value and cultural sxotem}

These responses were similar to given barrier "D" but differed in the emphasis placed on the basic values of one's owm culture rather than the inability to understand another culture.

\section{Lack of understanding}

Here it was stated that people did not want to understand each other. Others believed that students were too poorly trained and prepared even to encounter people of their owm background. 


\section{Lack of trust}

An antecedent to a lack of understanding may be the lack of trust mentioned here. Communication may be obstructed by a lack of "respect" and "a climate of mutual mistrust between races."

\section{Unvillingness to risk self-exposure}

Here was expressed the inability of people to remove their masks and let others see them without their social/professional roles. The relationship of social worker/client was seen as an authoritarian one. Others saw the social worker as a "patronizing do-sooder" unable to relate to his client in an honest and open manner.

\section{Other}

This category is a grouping of all the responses that occurred only once or twice from the total number of responses. It includes: poor listening habits, lack of positive regard between humans, emotionality of encounter, lack of mutual feedback, imoring nonverbal messages, institutionalized racism, and a lack of personal contact between races.

These results indicate that the largest percentage of responses (24.5\%), saw judging with negative and/or positive expectationg as the most critical barrier to communication between white social work students and black and chicano clients. A close second was one's own value and cultural system with $19.5 \%$ of the total responses. It should he noted that this barrier was formed from student responses to the questionnaire and was not a given barrier. 
After that the responses dropped to $11.0 \%$ for inadequate knowledge of other cultures, and $9.5 \%$ for lack of understanding.

\section{PART V OVERCOMTMG THE BARRTIRS}

In order to determine the best ways to overcame barriers which students see as existing between white students and black and chicano clients we developed section $V$ in our questionnaire.

Section A. Do you feel the School of Social Work should include in its program ways for students to overcome these communication barriers?

The overwhelming majority of both whites (89.0\%), and nonwhites (81.0\%), believe that the School of Social Work should include in its program ways for students to overcome coumunication barriers.

Section B. Do you feel that the PSU School of Social Work 18 providing students with experiences that would overcome these comminication barriers?

$57.0 \%$ of the whites and $59.0 \%$ of the non-whites do not think that the School of Social Work is providing students with experlences that would overcome communication barriers. Thus, while most respondents feel that the School of Social Work should proFide students with help in overcoming barriers, a majority do not believe that the School is presently meeting this responsibility. 
Section C. The following are suggested ways of overcoming these commuication barriers within the School of Social Work. In your opinion please rate their effectiveness.

TABLE IX OVERCOMTNO BARRTIRS

\begin{tabular}{|c|c|c|c|c|}
\hline \multirow{2}{*}{ Overcoming Barriers } & \multicolumn{2}{|c|}{ white } & \multicolumn{2}{|c|}{ non-wint te } \\
\hline & effective & $\begin{array}{c}\text { not } \\
\text { effective }\end{array}$ & effective & $\begin{array}{c}\text { not } \\
\text { effective }\end{array}$ \\
\hline comm course & $71.5 \%$ & $28.5 \%$ & 71.58 & $28.5 \%$ \\
\hline history course & $63.0 \%$ & $37.0 \%$ & $54.5 \%$ & $45.5 \%$ \\
\hline field experience & $87.0 \%$ & $13.0 \%$ & $71.5 \%$ & $28.5 \%$ \\
\hline live in experience & $85.5 \%$ & $14.5 \%$ & $66.5 \%$ & $33.5 \%$ \\
\hline $\begin{array}{l}\text { admit more black } \\
\text { and chicane students }\end{array}$ & $57.0 \%$ & 43.08 & 68.08 & $32.0 \%$ \\
\hline
\end{tabular}

In general our findings show that students feel that experiential ways of overcoming barriers, such as a field expertence or live-in experience, are more effective than other ways such as course work in either cross-cultural communication or black and chicano culture/mistory. A significant difference between the way whites and non-whites responded was on the question to include more black and chicano students in the School of Social Work. More non-wites felt that this would be an effective means to overcome barriers, while fewer whites tended to see it as effective. This appears algnificant considering the fact that white students saw other ways of overcoming communication barriers as more 
effective. Perhaps this is related to the lack of communication between students (black/chicano and wite) in the School of Social Work, which has been indicated by other responses to the questiomaire and it may reflect a feeling by whites that the inclusion of more blacks and chicanos in the program is not seen as a solution but rather a compounding of the problem which already exists.

Section D. What are other waye you feel the School of Soctal Work employ to overcome communication barriers?

Fifty students responded to this question which asked for other ways the School of Social Work could employ to overcome communication barriers. The following responses are from greatest to loweet frequency.

The most frequent responses stated that the School needed more activities that would foster more contact between students and bring all students together outside of the clasg room. The words informal, more personal, social, and extra-curricular were used to describe this need.

The next most frequent responses to question $D$ were that the School needed to reduce the size of its classes and promote more student interactions in classes with less lecturing by instructors. These students apecified role playing, seminars, encounter and discussion groups. Large class size was seen as a barrier to communication between all students and between students and faculty. 
Some students believed barriers would be reduced by bringing to the class room lecturers and leaders from the non-white community who would hold workshops and speak to classes. This would provide the white etudents with exposure to the non-white and his experience. It was also stated that minority lecturers and leaders should remain in social work class rooms and be hired as faculty and administrators. And it was suggested that minority students should design and teach classes or sections of classes that dealt with communication across ethnic lines. This implies that whites teaching whites about non-whites is not seen as an effective way to reduce commaication barrers.

Several white students believed that the School of Social Work was lowering its entrance requirements for non-whites and this created a commication barrier between white and non-white. These students auggested some kind of pre-admittance test that would provide equality and also identify and reject people who showed racial prejudice.

Other white atudents otated that a communication barrier exists when minority students "insist on maintaining a veparate group identity." They opecified "hushed meetings" and exclusive clubs such as the non-white caucus. They see the school of Social Work suffering from a lack of communication and interaction among all students. They believe issues must be confronted in formms open to everyone; closed meetings only promoted "racism, misunderstanding and hostility." 
There was a wide variety of responses to question $D$ but one theme stands out. Thirty-nine of the fifty responses expressed a need for better relationships between all social work students by having smaller classes, more social and extracurricular activities and discouraging separate group identities and unequal admittence rules. This implies that before the School of Social Work can begin to help students overcome the barriers to commanication in the student/client relationship, it will first have to overcome the barriers that students have stated exist between "student and student, white and non-inite, student and faculty" within the School of Social Work.

Section E. In your opinion what priority would you give the task of overcoming communication barriers between white social work students and black and chicano clients considering the other functions and tasks of the School of Social Work at PSU.

More than half the non-whites $(59.0 \%)$ felt that this area deserves to be rated high in priority. A relatively amall percentage of both wites $(19.5 \%)$ and non-whites (18.0\%) felt that the takk of overcoming communication barriers should be given low priority in relation to other tasks the School of Social Work mast perform. This is consistent with the findings of Section A which asked whether students felt the School should address itself to overcoming communication barriers. They felt it should and here again we find that overcoming communication barriers should receive above average priority. 


\section{PART VI}

Section A. In your experience as a social work student, how many black chicano clients have you worked with?

We felt that experience working with black and chicano clients would have some effect on the ways students felt about the problem of communication barriers. If they had little or no experience working with minority clients, they might be less inclined to feel that barriers exist.

The responses to this question showed that the School of Social Work provides very little experience with black and chicano clients, particularly to white social work students, $42.5 \%$ of whom stated they had no experience with black or chicano clients. The non-whites had more experience with blacks and chicanos but even among this group, $22.5 \%$ have had none.

Section B. Prior to admission to the School of Social Work how many black/chicano clients have you worked with?

The responses to section B show that prior to enrolling at the School of Social Work, $52.0 \%$ of whites and $57 \%$ of non-whites have had some experience working with black or chicano clients.

\section{PARI VII}

It is important to our study that we know how you feel about this questionnaire. You're comments are extremely valuable.

Seventy-two students responded to Part VII. The most frequent responses to this question were placed in the five following categories: 1. Positive statements regarding questionnaire. 
2. Negative statements regarding questionnaire. 3. Suggestions for further research. 4. Statements that questionnaire was biased. 5. Statements that results of questionnaire be given top priority.

\section{Positive statements}

The following positive terms are quoted from the total responses: The questionnaire was "comprehensive, good, useful, clear, relevant, honorable, well done, interesting, important, adequate, and well thought out."

\section{Negative statements}

The following negative terms are quoted from the total responses: "Awkward, not well defined, too long, couldn't read directions, hard to understand, one sided, made me mad, too hard to answer, obtuse, too limited, poorly worded, biased, assumes too much, and not relevant."

\section{Suggestions for further research}

Some responses implied that we had neglected key factors that cause communication problems between ethnic groups and suggested areas for further research. These suggestions included studies on: The socio-education level between ethnic groups. Black and chicano social work students and white clients. White social work professionals and black/chicano professionals. Racism at the School of Social Work. And a study to overcome the School of Social Work's "bureaucratic and cultural problems." 
4. Statements that questionnaire was biased.

Several people felt that we had created a problem that "wasn't as evident as questionnaire inferred," that we had "presented obvious barriers to compell a choice of yes" and "the degree of the communication barrier was irrelevant."

5. Statements that results of questionnaire be utilized

The responses placed in this category expressed concern that the results of this questionnaire be used to bring about changes in the School of Social Work, that it must result in some positive action or it would be "Just another ploy to placate the students."

\section{SUMMARY}

Because of the number and variety of responses, particularly in the open-ended questions, it is difficult to sumarize briefly the results of this study. There are a few general statements which can be made, however.

The responses to the questions on the proposed barriers reveal that, in general, non-whites saw all of our proposed barriers as more significant than did white students.

The most critical proposed barriers chosen by all students concerned culture and value systems rather than language.

Black and chicano bias against the white social worker was chosen as the most significant communication barrier to be added to our proposed list.

Over $80 \%$ of all students believed that the School of Social Work should include in its program, ways for students to overcome 
communication barriers and a majority of students noted that the School was not presently helping them accomplish this task. Students indicated that the best way to overcome communication barriers within the School was through experiential modes of education. And, in addition, there needs to be an improvement in the relationship between all social work students before the School could help improve the student/client relationship. $42 \%$ of the whites and $25 \%$ of the non-whites marked that the School had provided them with no experience in working with the black or chicano client, although the majority of all respondents stated that they had some experience with blacks and chicanos prior to enrolling at School.

And finally, students feel overcoming commuication barriers is an area which requires much more emphasis than is currently being given it. 
$\checkmark$ IMPLIGATIONS 


\section{TMPLICATIONS}

The results of our questionnaire indicate that students are aware of barriers to communication between white social work students and black and chicano clients. More importantly, social work students see the School of Social Work as having an essential role in providing them with the opportunities to develop skills in this area. This tends to support melicia Mizio's statement that "early in training social workers must learn to subject themselves to critical self-examination with regard to their feelings... they must use this technique to examine how their racial attitudes affect their work with minority clients. ${ }^{46}$ our data suggests many ways to overcome barriers. Out of these, three (3) were more significant in terms of response. They are as follows:

1. Field placements with black and chicano clients.

2. A live in situation with black and chicanos.

3. Change in the School setting itself, aimed at improving communication and relationships between all students.

These methods are considered experiential rather than the traditional didactic approach to learning found in the class room. This section is thus concerned with ways in which the School of Social Work can implement the student's suggestions for change.

We propose that a field unit be established to work specifically with black and chicano clients within their communities. 
This unit should be comprised of both white and non-white students. The field instructor(s) should have skill in the teaching of cross cultural commication as well as being able to provide the experiences necessary to overcome barriers. In order to accomplish the goals of this proposal, students must receive feedback from the clients, the field instructor(s) and each other. The thrust of the field unit is more one of process of helping students overcome barriers rather than product such as placing a child for adoption. The field instructor should be autonomous and responsible primarily to the students and their clients rather than agency based.

Since the kind of field placement envisioned here is not now specifically found in the community, the formulation and articulation of such a proposal is left for the person(a) who operationalize this by writing a grant for funding. This could be the project for a future practicum group. Indeed, it is our hope that this research material be used as a beginning of such a pursuit.

A live in experience with blacks and chicanos was felt to be an effective method of overcoming barriers. We propose that black and chicano people in the community be contacted who would be willing to house white social work students for a limited amount of time. Students would then be given an opportunity to experience directly the life style of minority groups and gain understanding of the problems they encounter in a racist society. Students should receive academic credit for this experience. 
While not a traditional method of learning, we feel such experiences would broaden the knowledge base of students in ways the didactic methods are not able. "Learning is a process of discovery by the learner and uses procedures such as learning by doing... There is a decreasing emphasis on the transmittal techniques of traditional teaching and increasing emphasis on the experimental techniques which tap the experience of the learners and involve them in analyzing their experience. The use of lectures, canned audiovisual presentations and assigned reading tend to fade in favor of discussion, laboratory, simulation, field experience, team projects or other action learning techniques." 47

While one field unit and/or a live in situation option may help to overcome communication barriers for those involved, its scope is limited to those students placed in the unit or homes. There must also be some way of imparting knowledge and skills in this area to the total school population.

our third proposal concerns improving relationships and focusing on problems among students at the School of Social Work. "... whether or not contact will decrease the amount of prejudice depends on the nature of the contact. While casual, superficial contact may reinforce prejudice, contacts that bring knowledge and acquaintance are likely to engender sounder beliefs concerning racial groups." 48 .

If classes are modeled after National Training Laboratory groups with attention paid to size of the group (amall) and 
balance in terms of whites and non-whites, students could not only, interact but also study the process. Capable faculty would be responsible for providing insight and feedback regarding overcoming barriers. They would need to be knowledgeable regarding communication skills and be able to challenge students. This situation could be established either as a methods course or a required part of the core curriculum.

Since many persons attracted to the field of social work profess liberal attitudes, they may not see the need for a course on cross cultural communication and racism. Therefore, it is our observation that such a course(s) must be required for all students. As Amold states in reference to similar curriculum, "It reflected a comitment on the part of faculty to struggle with materials and begin to face this problem which they felt had particular relevance to the social work profession and social work education." 49

While almost everyone recognized the problem of racism and communication barriers between ethnic groups, there is very little being done to eradicate them. After three years, the nonwhite policy goals statement (see Appendix D) of Portland State University School of Social Work, has yet to be implemented. This was adopted as a goal statement, February, 1972. Without the allocation of funds to recruit non-white students and to offer sufficient financial remuneration to attract non-white faculty, it seems evident that there is, in fact, little real 
commitment to this goal statement. In order to implement this or our proposals, there needs to be a real commitment on the part of both faculty and students.

Students indicated that a shift in the priorities of the School of Social Work 18 needed to facilitate communication between white social work students and black and chicano clients. It is a moot point to discuss strategies for change without a group (either from the faculty, students, or community) concerned with these issues and proposals. Currently statistics on the admission of non-white students and hiring of non-white faculty indicate a lack of commitment to this isaue on the part of Portland State Oniversity School of Social Work. (See Appendix C and also D for non-white policy statement.) There are two strategies suggested by Burke 50 which are appropriate; however, in terms of application to both faculty groups and student groups which could be used to apply pressure for change. The first strategy, "behavioral change," is more applicable to a faculty group-those in power. Participation in a group has been found to be a major force for changing individual behavior. The object of this strategy is to induce change in a system or subsystem by altering the behavior of either the system's members or influential representatives of the system. Thus, if a faculty group interested in addregsing the issue of communication and racism, could involve those with more power but who have less interest in the problems, the likelikood of changing the attitudes 
VI CONCLUSIONS 


\section{CONCLUSION}

We have attempted to explore the attitudes of social work students concerning communication barriers between white social work students and black and chicano clients. By developing and administering a questionnaire to elicit opinions, we arrived at the following conclusions:

1. The most critical barriers were seen to be culture and value gystems and black/chicano bias against the white social worker.

2. Students felt the Portland State University School of Social Work should include ways to overcome barriers in its program but is neither providing course content nor field experience with non-whites to facilitate this.

3. The best way to overcome barriers is through experiential modes of education--both with clients and with students at the School.

This is important considering the fact that the literature and our study demonstrate that social work education should be addressing this issue.

We have suggested several appropriate ways that can be utilized by the Portland State University School of Social Work to assigt students in becoming aware of, and changing, their own biased attitudes regarding racial differences. We have found that such attitudes contribute to the maintenance of communication barriers. It is essential for the School of Social Work to be 
cosnizant that "most of us, as members of a majority group, have absorbed discriminatory attitudes in growing up and often have little awareness of this. It would require some careful seif-scrutiny to sort out these prejudices; and strenuous ruthless honesty, to admit to ourselves the presence of stereotyped thinking about minority groups. 51

Thus far, little attention and emphasis has been placed on this area in graduate school. The consequences of this lack of commitment are the maintenance and perpetuation of the doctrine of color blindness and the imposition of dominant white cultural values on all. 


\section{APPENDICES:}

A Questionnaire

B Additional Statistica

C Non-white Faculty and Students at Portland State University School of Social Work since 1962

D Non-white policy goal atatement 
APPENDIX A

\section{QUESTIONNAIRE}

I. INTRODUCTORY STATEMENT

Communication can be seen as the giving and receiving of information, signals or messages by talk, gestures, writing, etc. A communication barrier may be defined as any hindrance to the task of communicating. It is generally recognized that communication skills are important in order to function effectively as social workers.

The purpose of this study is to determine what white social work students see as barriers to communication between themselves and black and chicano clients, and 1ts implications for education at Portland State University School of Social Work.

II. GENERAL INFORMATION

A. Age

B. Sex: $I T$ Male $I T$ Female

C. Ethnic Background: $I T$ White; $I T$ Black; $I T$ Chicano; $I$ Native American; IT Oriental; $L$ Other

D. Career Goals; $\square$ Direct Services; $I T$ co; IT Facilitative Services; II Other - Specify

E. Present Field Work Setting: $\frac{T}{T}$ Direct Services; $I T$ Co; II Facilitative Services; II Other - Specify

F. Marital status: $I T$ Single; $I T$ Married; $I T$ widowed; II Divorced; IT Separated.

G. IT 1st Year Student $I$ 2nd Year Student 
QUESTIONNAIRE

Page Two

III

The following are five possible communication barriers and an explanation of each. Please indicate (by checking the approprlate box) your feelings about the extent to which each proposed barrier blocks communication between white social work students and black or chicano clients.

To answer questions 1, "In your oplnion..." use the following scale. Your opinion is defined as your own subjective judgment.

MARK THIS

IT None or Little

II Medium

II High

IT Very High
IF YOU MEAN THIS

Not a real barrier, with no effect on communication.

Slight barrier, but communication would proceed.

Marked barrier with a negative impact on communication.

Definite barrier with a total breakdown in communication

If any of the questions do not apply to your experience or opinion, please write NA (not applicable) next to the pertinent columns.

A. Use of same words but different frame of reference.

White soclal work students and black and chicano clients use words which are a product of their own experlence. Since white students and black and chicano clients have different experiences, the words they use while the same, will reflect different meanings. 
QUESTIONNAIRE

Page Three

1. IN YOUR OPINION IS THIS A BARRIER TO EFFECTIVE COMMUNICATION BETWEEN WHITE SOCIAL WORK STUDENTS AND. . •

BLACK CLIENTS

$I$ None or Little

$I$ Medium

I/ High

IT Very High

\section{CHICANO CLIENTS}

$I$ None or Little

$I 7$ Medium

I $\mathrm{HIgh}$

II Very High

2. IS THIS ANSWER BASED ON PERSONAL EXPERIENCE?
IT Yes
IT Yes
$I 7$ No
II No

B. Inadequate skill in other language.

A communication barrier exists when white social work students don't have an understanding of client's indigenous language 1.e., Black English/Spanish.

1. IN YOUR OPINION IS THIS A BARRIER TO EFFECTIVE COMMUNICATION BETWEEN WHITE SOCIAL WORK STUDENTS AND.. .

BLACK CLIENTS

$I$ None or Little

IT Medium

IT High

IT Very High

\section{CHICANO CLIENTS}

I None or Little

IT Medium

IT High

IT Very High

2. IS THIS ANSWER BASED ON PERSONAL EXPERIENCE?

IT Yes

IT Yes

II No
$I$ No 
QUESTIONNAIRE

Page Four

C. Using language other doesn't understand

Social work jargon and words gained through advanced education may not be understood by cllents.

1. IN YOUR OPINION IS THIS A BARRIER TO EFFECTIVE COMMUNICATION BETWEEN WHITE SOCIAI, WORK STUDENTS AND . . •

BLACK CLIENTS

IT None or Iittle

1 Medium

IT Righ

II Very High

\section{CHICANO CLIENTS}

I None or Little

II Medium

I High

IT Very High

2. IS THIS ANSWER BASED ON PERSONAL EXPERIENCE?

$I$ Yes

II Yes

IT No

$I$ No

D. Inadequate knowledge of other cultures.

Different cultures present different value systems which if not understood w111 hinder communication.

1. IN YOUR OPINION IS THIS A BARRIER TO EFFECTIVE COMMUNICATION BETWEEN WHITE SOCIAL WORK STUDENTS AND . . .

BLACK CLIENTS

$I$ None or Little

IT Medium

II High

IT Very High
CHICANO CLIENTS

II None or Iittle

II Medium

IT High

II Very High

2. IS THIS ANSWER BASED ON PERSONAL EXPERIENCE?

II Yes

IT Yes

$I$ No

$I$ No 
QUESTIONNAIRE

Page Five

E. Judging with negative and/or positive expectations

When white social work students are not able to perceive the individuality of his client but is influenced by black/chicano stereotypes whether negative or positive, any fudgment will hinder communication.

1. IN YOUR OPINION IS THIS A BARRIER TO EFFECTIVE COMMNICATION BETWEEN WHITE SOCIAL WORK STUDENTS AND . .

BLACK CLIENTS

$I$ None or Little

II Medium

$I$ HIgh

II Very High

\section{CHICANO CLIENTS}

$I$ None or Little

$I$ Medium

II H1gh

II Very High

2. IS THIS ANSWER BASED ON PERSONAL EXPERIENCE?

IT Yes

IT No
I Yes

I No

A. DO YOU FEEL THAT THERE ARE COMMUNICATION BARRIERS BETWEEN WHITE SOCIAL WORK STUDENTS AND BLACK AND CHICANO CLIENTS OTHER THAN THE ONES STATED ABOVE?

$\square$ Yes

II No

IT Don't know

B. IF YES, PLEASE STATE OTHERS WHICH YOU SEE AS SIGNIFICANT.

C. IN YOUR OPINION, WHAT DO YOU THINK ARE THE MOST CRITICAL, BARRIERS TO COMMUNICATION? (INCLUDE BOTH OUR PROPOSED BARRIERS AND YOURS). 
QUESTIONNAIRE

Page Six

V OVERCOMING THE BARRIERS

A. DO YOU FEEL THE SCHOOL OF SOCIAL WORK SHOULD INCLUDE IN ITS PROGRAM WAYS FOR STUDENTS TO OVERCOME THESE COMMUNICATION BARRIERS?

IT Yes

IT No

B. DO YOU FEEL THAT THE PSU SCHOOL OF SOCIAL WORK IS PROVIDING STUDENTS WITH EXPERIENCES THAT WOULD OVERCOME THESE COMMUNICATION BARRIERS?

IT Yes

17 No

IT Don't Know

C. THE FOLLOWING ARE SUGGESTED WAYS OF OVERCOMING THESE COMMUNICATION BARRIERS WITHIN THE SCHOOL OF SOCIAL WORK. IN YOUR OPINION PLEASE RATE THEIR EFFECTIVENESS.

a. Course in cross-cultural communication

Not effective

12

3

$\underset{5}{\text { Very ef fective }}$

b. Course in black and chicano culture/history.

Not effective

12

3

Very effective

$5 \quad 6$

c. Field experience with black and chicano clients with emphasis on communication skills

Not effective

12

23

34

Very effective

$5 \quad 6$

d. Live-in experience with blacks and chicanos (such as spending days/weeks with people in their own home).

Not effective

1 ?

23

Very effective

56

e. Include more black and chicano students in the School of Social Work.

Not effective

1

2

3

Very effective

$4 \quad 5$ 
QUESTIONNAIRE

Page Seven

D. WHAT ARE OTHER WAYS YOU FEEL THE SCHOOL OF SOCIAL WORK CAN EMPLOY TO OVERCOME COMMUNICATION BARRIERS.

E. IN YOUR OPINION, WHAT PRIORITY WOULD YOU GIVE THE TASK OF OVERCOMING COMMUNICATION BARRIERS BETWEEN WHITE SOCIAL WORK STUDENTS AND BLACK AND CHICANO CLIENTS CONSIDERING THE OTHER FUNCTIONS AND TASKS OF THE SCHOOL OF SOCIAL WORK AT PSU.

IT Very High

I High

II Medium

$I$ Low

II Very Low

VI

A. IN YOUR EXPERIENCE AS A SOCIAL WORK STUDENT, HOW MANY BLACK/ CHICANO CLIENTS HAVE YOU WORKED WITH?

$I$ None II $1-3 \quad I I 4-6 \quad I T 7$ \& Over

B. PRIOR TO ADMISSION TO SCHOOL OF SOCIAL WORK, HOW MANY BLACK/ CHICANO CLIENTS HAD YOU WORKED WITH?

$I T$ None II $1-3 \quad I I \quad 4-6 \quad I T 7$ \& Over

VII COMMENTS ABOUT STUDY

IT IS IMPORTANT TO OUR STUDY THAT WE KNOW HOW YOU FEEL ABOUT THIS QUESTIONNAIRE. YOUR COMMENTS ARE EXTREMELY VALUABLE. 
APPENDIX B

PART $\nabla$ OVERCOMING THE BARRIERS

Section C. The following are suggested ways of overcoming these

Communication barriers within the School of Soclal Work. In your opinion please rate their effectiveness.

a. Course in cross-cultural communication Not effective

$12 \quad 3$

\begin{tabular}{ccc} 
& Very effective & \\
4 & 5 & 6 \\
$30.0 \%$ & $32.0 \%$ & $9.5 \%$ \\
$23.5 \%$ & $23.5 \%$ & $23.5 \%$ \\
\hline
\end{tabular}

\begin{tabular}{lrrrrrr} 
White & $2.5 \%$ & $14.0 \%$ & $12.0 \%$ & $30.0 \%$ & $32.0 \%$ & $9.5 \%$ \\
Non-white & $0.0 \%$ & $19.0 \%$ & $9.5 \%$ & $23.5 \%$ & $23.5 \%$ & $23.5 \%$ \\
\hline
\end{tabular}

b. Course in black and chicano culture/history Not effective

Very effective

\begin{tabular}{lrrrrrr} 
& 1 & 2 & 3 & 4 & 5 & 6 \\
White & $4.0 \%$ & $13.0 \%$ & $20.0 \%$ & $35.5 \%$ & $20.0 \%$ & $7.5 \%$ \\
Non-white & $13.5 \%$ & $23.0 \%$ & $9.0 \%$ & $18.0 \%$ & $23.0 \%$ & $13.5 \%$ \\
\hline
\end{tabular}

c. Fleld experience with black and chicano clients

\begin{tabular}{lcccccc}
\hline Not effective & & \multicolumn{3}{c}{ Very effective } \\
White & 1 & 2 & 3 & 4 & 5 & 6 \\
Non-white & $2.5 \%$ & $4.5 \%$ & $6.0 \%$ & $19.0 \%$ & $40.0 \%$ & $28.0 \%$ \\
\hline
\end{tabular}

d. Live-in experience with blacks and chicanos

\begin{tabular}{lcccccc}
\hline Not effective & & & & \multicolumn{3}{c}{ Very effective } \\
& 1 & 2 & 3 & 4 & 5 & 6 \\
White & $1.0 \%$ & $6.0 \%$ & $8.5 \%$ & $19.5 \%$ & $33.5 \%$ & $32.5 \%$ \\
Non-white & $4.5 \%$ & $14.5 \%$ & $14.5 \%$ & $23.5 \%$ & $19.0 \%$ & $24.0 \%$ \\
\hline
\end{tabular}

e. Include more black and chicano students in the School of Soctal Work Not effective

1

White

$13.0 \%$

Non-white $\quad 14.0 \%$

2

$17.0 \%$

3

$14.0 \%$

$13.0 \%$

$4.0 \%$

$26.0 \%$

Very effective

5

$18.0 \%$

$18.5 \%$

6

$18.2 \%$

$13.0 \%$

$32.0 \%$ 
APPENDIX C

Portland State University School of Soclal Work was officlally opened in September 1962. The following chart indicates faculty composition.

TABLE I

\begin{tabular}{|c|c|c|c|c|c|}
\hline YEAR & PART-TIE & FULL-TIEE & \multicolumn{2}{|c|}{ NON-WHITE } & TOTAL \\
\hline $1962-63$ & 4 & 3 & 1 & Black & 7 \\
\hline $1963-64$ & 4 & 4 & 1 & Black & 8 \\
\hline $1964-65$ & & 7 & 0 & & 7 \\
\hline 1965-66 & 1 & 10 & 0 & & 11 \\
\hline $1966-67$ & 1 & 12 & 0 & & 13 \\
\hline $1967-68$ & 4 & 12 & 0 & & 16 \\
\hline $1968-69$ & 2 & 12 & 0 & & 14 \\
\hline $1969-70$ & 3 & 15 & 2 & $\begin{array}{l}1 \text { Puerto Rican } \\
1 \text { Oriental }\end{array}$ & 18 \\
\hline $1970-71$ & 3 & 19 & 2 & $\begin{array}{l}1 \text { Puerto Rican } \\
1 \text { Orlental }\end{array}$ & 22 \\
\hline $1971-72$ & 5 & 20 & 3 & $\begin{array}{l}1 \text { Puerto Rican } \\
1 \text { Orlental } \\
1 \text { Black }\end{array}$ & 25 \\
\hline $1972-73$ & 6 & 20 & 4 & $\begin{array}{l}2 \text { Puerto Rican } \\
1 \text { Black } \\
1 \text { Am. Indian }\end{array}$ & 26 \\
\hline
\end{tabular}

From September 1962, when the School of Soc1al Work first opened Its doors to graduate students, the number of students increased its enrollment from a total of 24 students to a total of 86 students enrolled in September 1972. 
Table II below summarizes the number of students enrolled and graduated from 1962 to present.

TABLE II

\begin{tabular}{ccc}
\hline YRAR & $\begin{array}{c}\text { NO. OF TOTAL STUDENTS } \\
\text { WHO EARNED DEGREE }\end{array}$ & $\begin{array}{c}\text { NO. OF NON-WHITE STU- } \\
\text { DENTS WHO EARNED DEGREE }\end{array}$ \\
\hline & & 3 \\
1964 & 15 & 1 \\
1965 & 19 & 1 \\
1966 & 21 & 1 \\
1967 & 27 & 1 \\
1968 & 28 & 3 \\
1969 & 46 & 5 \\
1970 & 51 & 3 \\
1971 & 58 & 16 \\
1972 & 86 & \\
& & \\
\hline
\end{tabular}

The table shown above does not include forelgn students since they are not considered part of the non-white classification. 
APPENDIX D

The following is the existing Policy Statement Goals at Portland State UnIversity School of Soctal Work.

"We the students, faculty, and professional practice community assoclation with the Portland State Unfversity School of Soclal Work subscribe to the following polfcy statements:"

1. That a minimum of $33-1 / 3$ of the first year students be non-white. This percentage will be equally distributed among the American Indians, Asian Amerfcans, Blacks and Chicanos.

2. That a sustained and systematic effort to find academically qualified non-whites be made.

3. That special and conditional students admitted be provided with formal tutorial services.

4. That the distribution of stipends be the responsibility of the Admissions Panel.

5. The Director of Admissions will be responsible for implementing a systematic program for recruftment of non-white social workers beginning at the high school level and extending through all undergraduate institutions in the Western States.

6. The Director of Admissions will present a semi-annual report to faculty and students specifying the recruitment efforts being made.

7. That the Dean of the School reassess faculty work loads and assign faculty members to write proposals of grants for the school that will provide faculty positions to be filled by non-white professionals and will provide stipends for both undergraduate and 
graduate non-white students.

8. The faculty will encourage and assist students in writing grant proposals as research practicums, proposals that will provide faculty positions for non-white professionals, field units that will focus on working with non-white populations, and stipends for both undergraduate and graduate students.

9. The Dean will establish formal communication that will connect this school with all potential resources for faculty on the doctoral as well as Master's level.

10. Non-white professionals will be based to this faculty because of their expertise in one or more areas of the curriculum and not because of their race.

11. All courses in this school will include content explicitly related to the cultures and needs of non-white people.

12. The School of Social Work will take responstbility for offering educational programs on non-white groups to all social service personnel working in Oregon agencies.

13. All students in this graduate school will have the opportunity to involve themselves with meaningful academic content and field practicum experience with people of other races and cultural orientations other than their own.

14. The Dean will implement an aggressive public relations program that will give the School of Social Work greater visibility among undergraduate students and the general community.

15. The School will assemble and maintain a current roster of non-white social service personnel with baccalaureate, Master's, and doctoral 
degrees who are currently in this area or are interested in coming to this area and will circulate that list quarterly to all social service agencies so that they can notffy non-white soclal workers of personnel vacancies on all levels.

16. The faculty, students and practice community associated with Portland State University School of Social Work will be bound in principle and practice to this policy statement.

17. The Administrative Committee will review any charges of violations of this polfcy statement, in whole or in part, by any of the contracting parties.

18. An Ad Hoc Committee will be set up for an annual review and revision of this policy statement. 
FOOTNOTES

1. Dance, Frank E. X. "The Concept of Communication." The Journal of Communication, Vol. 20 (June, 1970), p. 208.

2. Websters New World Dictionary of The American Language, College Edition (Cleveland and New York, 1960), p. 296.

3. Curry, Andrew. "The Negro Worker and the White Client: A Commentary on the Treatment Relationship." Social Casework, Vol. XIV (March, 1964), p. 131. (This article included as it also is concerned with white social worker and black client.)

4. Fenalson, Anne F. Essentials in Interviewing. (New York Revised 1962), p. 4.

5. Fibush, Esther. "The White Worker and the Negro Cllent." Social Casework, Vo1. XLVI (May, 1965), p. 273.

6. Kadushin, Alfred. "The Racial Factor in the Interview." Social Work, (May, 1972), p. 88.

7. Curry, p.132.

8. Kadushin, p. 89 .

9. Fibush, p. 272 .

10. Stiles, Evelya, et al. "Hear It Like It Is." Social Casework. Vol. 53, (May, 1972), p. 293.

11. Banks, George P. "The Effects of Race on One-to-One Helping Interviews." Social Service Review, Vol. 45, (Feb. 1971), p. 137.

12. Morales, Armando. "The Collective Preconsclous and Racism." Soclal Casework, Vo1. 52, (May, 1971), p. 286.

13. Kadushin, p. 88 .

14. Morales, p. 286.

15. Benjamin, Alfred. The Helping Interview. (New York, 1969), p. 97.

16. Schubert, Margaret. Interviewing in Soclal Work Practice. (New York, 1971), p. 32.

17. Mehrabian, Albert and Henry Reed. "Some Determinants of Communication Accuracy." Psychological Bulletin, Vol. 70, (Nov. 1968), p. 366. 
18. Wedge, Bryant. "Toward a Science of Transnational Communication." Group for the Advancement of Psychlatry, Vo1. IV Part 1 (Dec. 1959), pp. 383-394.

19. Kadush In, p. 92.

20. Daniels, Jack L. Factors in Effective Communication Between Professionals, Non-Professionals and Poor People. Ph.D. Thes1s, (University of P1ttsburgh, 1968), Microf11m p. 121 .

21. Agullar, Ignacio, "Initial Contacts with Mexican American Families." Soclal Work, Vol. 17 (May, 1972), p. 66-70.

22. Knol1, F. R. "Casework Services for Mexican Americans." Soclal Casework, Vol. 52 (May, 1971), p. 284.

23. Ramsey, Glenn and Beulah Hodge. "Anglo-Latin Problems as Perceived by Public Service Personnel." Soctal Forces, Vol. 37 (May, 1959), Pp. 339-348.

24. Schubert, p. 33 .

25. Danlels, p. 43-44.

26. Harding, Talbot. "Diagnosis and Treatment of Communication Fallure." Soclal Casework, Vol. 49 (Feb. 1971), p. 86.

27. Ramos, Juan. "Ed1torlal Notes." Soclal Casework, Vol. 52 (May, 1971), p. 324.

28. Fenalson, p. 4 .

29. Mizio, Emelicia. "White-Worker-Minority Client." Social Work, Vol. 17 (May, 1972), p. 84.

30. Konapke, Gisele. Social Group Work: A Helping Process. (New Jersey, 1963), p. 89.

31. B1llingsley, Andrew. "Black Families and White Soclal Science." Journal of Soctal Issues, Vo1. 26 (March, 1970), p. 132-33.

32. Ramsey and Hodge, P. 339-348.

33. Ramos, p. 324 .

34. Flbush, P. 272.

35. Stiles, et al, p. 293. 
36. Seligman, Michele. "The Interracial Casework Relationship." Smith College Studies In Social Work, Vol. 39 (Nov. 1968), p. 84 .

37. Archibald, Robert D. Cross-Cultural Communication: An Interpersonal Perspective. Ph.D. Thesis (University of Utah, 1971), p. 59 .

38. Ramsey and Hodge, p. 346.

39. Shannon, Barbara E. "Implications of White Racism for Soclal Work Practice." Soclal Casework, Vol. 51 (May, 1970), p. 275.

40. Kadush in, p. 91.

41. Bloch, Julla B. "The White Worker and the Negro Client in Psychotherapy." Soclal Work, Vol. 13 (April, 1968), p. 41.

42. Benjamin, p. 96.

43. St1les, et al, p. 298.

44. Curry, p. 134 .

45. Stiles, et al, p. 292.

46. Mizio, p. 86.

47. Knowles, Malcolm S. "Innovations and Teaching Styles and Approaches Based on Adult Learning." Journal of Education for Soclal Work, Vol. 8 (Spring, 1972), p. 35.

48. Kurokawa, Minako. "Mutual Perceptions of Racial Images: White, Black and Japanese Americans." Journal of Soclal Issues, Vol. 27 (Apr11, 1971), p. 233.

49. Arnold, Harold. "American Racism: Implications for Social Work." Journal of Education for Soclal Work, C.S.W.E. Vol. 6 (Fall, 1970) p. 8.

50. Burke, Edmund M. "Citizen Participation Strategles." Journal of the American Institute of Planners (Sept. 1968), pp. 287-294.

51. 01ds, Victorla M. "Sit-Ins: Social Action to End Segregation." Soclal Work, Vol. 6 (Apr11, 1961), p. 104. 


\section{BIBLIOGRAPHY}

Aguilar, Ignacio. "Initial Contacts with Mexican American

Families." Social Work, 17 No. 3 (May, 1972), pp. 66-70.

Archibald, Robert D. Cross-Cultural Communication: An Interpersonal Perspective. Ph.D. Thesis. University of Utah, 1971. Xerox Co. Micro-film.

Arnold, Harold. "American Racism: Implications for Social Work." Journal of Education for Soctal Work, Vol. 6 非 (Fall, 1970), pp. 7-12.

Atenc1o, Tomas. "The Survival of La Raza Despite Social Services." Social Casework, (May, 1971) Vol. 52 非, pp. 262-268.

Bagley, C. "Migration, Race and Mental Health: A Review of Some Recent Research." Race, 9 (3) 1968, pp. 343-56.

Banks, George P. "The Effects of Race on One-to-One Helping Interviews." Soclal Service Review, Vol. 45 No. 2 (Feb. 1971), pp. 137-46.

Barrett and Perlmutter. "Black Clients and White Workers: A Report From the Field." Child Welfare, Vol. 50 No. 1 (Jan. 1972), pp. 19-24.

Beasley, Lou M. "A Beginning Attempt to Eradicate Racist Attitudes." Soclal Casework, (Jan. 1972), Vol. 53 No. 1, pp. 9-13.

Benjamin, Alfred. The Helping Interview. N.Y.: Houghton Mifflin Co. 1969.

Besel, Ronald Robert. The Construct Validation of an Opinion Survey Instrument. Ph.D. Thesis, Case Western University 1971. Xerox Co. Micro-film.

Billingsley, Andrew. "Black Families and White Social Science." Journal of Social Issues, Vol. 26 \#3, 1970, pp. 127-138.

Bloch, Julla B. "The White Worker and the Negro Client in Psychotherapy." Social Work, Vol. 13, No. 2 (April, 1968), pp. 36-42.

Bowles, Dorcas. "Making Casework Relevant to Black People: Approaches, Techniques, Theoretical Implications." Child Welfare, Vol. 48 No. 8, (Oct. 1969), pp. 468-75.

Brieland. "Black Identity and the Helping Person." ChIldren, Vol. 16 No. 5, Sept.-Oct. 1969, pp. 170-176.

Brislin, Richard. "Back Translation for Cross Cultural Research." Journal of Cross Cultural Psychology, Vol. 1 No. 3, Sept. 1970. 
Bryant, Eugene C., Isaac Gardner, Jr. and Morton Goldman. "Responses on Racial Attitudes as Affected by Interviewers of Different Ethnic Groups." Journal of Soctal Psychology, Vol. 70 No. 1, (Oct. 1966), pp. 95-100.

Bryant, Larry. "Black English: A Speech Apart." Oakland Tr1bune Nov. 9, 1969, p. 29.

Burke, Edmund M. "Citizen Participation Strategies." American Institute of Planners Journal, Vol. 34, No. 5, (Sept. 1968), Pp. 287-294.

Burns, C. E. "White Staff, Black Children, Is There a Problem?" Child Welfare, 50 (2) 1971, pp. 90-96.

Calla, V. F. "The Culturally Deprived Client: A Re-Formulation of the Counselor's Role." Journal of Counsellng Psychology, 13 (1) 1966, pp. 100-105.

Clark, Margaret. Health in the Mexican American Culture. U. C. Press Berkeley and L. A. 1959.

Cohen, J. "Race as a Factor In Soclal Work Practice. Race, Research and Reason." Soclal Work Perspectives (NASW) 1969, PP. 99-113.

Coles, Robert. "The Poor Don't Want to be Middle-Class. Selective Reading Series, No. 7, Calffornia State Department of Welfare.

Corkhuff, R. R. and R. Pierce. "Differential Effects of Therapist Race and Social Class Upon Patient Depth of Self-Exploration in the Initial Clinical Interview." Journal of Consulting Psychiatry, 31 (6).

Curry, Andrew E. "The Negro Worker and the White Client: A Commentary on the Treatment Relationship." Social Casework, Vol. XLV No. 3 (March, 1964), pp. 131-136.

Daniels, Jack. Factors in Effective Communication Between Professionals, Nonprofessionals and Poor People. Ph.D. Thesis, University of Pittsburgh, 1968. Xerox Co. Micro-film.

Daniel, Jack L. "The Facilitation of White-Black Communication." The Journal of Communication, Vol. 20, June 1970, pp. 134-141.

Dienstbier, R. A. "Positive and Negative Prejudice: Ineraction of Prejudice with Race and Soctal Desirability." Journal of Personality, 38 (2) 1970, pp. 198-215.

Erb, David Lloyd. Racial Attitudes and Empathy: A Guttman Facet Theory Examination of Their Relationships and Determinants. Ph.D. Thesis, Michigan State University 1969. Xerox Co. Micro-film. 
Ethnic Minorities in Soclal Work Education. Carl Scott Ed. Council on Social Work Education, Inc. N.Y. 1970.

"Fallacies in Myths, Old and New, About Blacks Call for Correction." Roche Report: Frontiers of Clinical Psychiatry. Mimeographed. Distributed for classroom use. Portland State University School of Soclal Work 1970.

Fenalson, Anne F. Essentials in Interviewing. Harper and Row, Publishers N.Y. Rev. 1962.

Fibush, Esther. "The White Worker and the Negro Client." Social Casework, Vol. XIVI No. 5 May 1965, pp. 271-277.

Fibush, Esther and Bi Alva Turnquest. "A Black and White Approach to the Problem of Racism." Soclal Casework, Vol. 5 No. 8 (Oct. 1970), pp. 459-466.

Flack, Michael. "Communicable and Uncommunicable Aspects in Personal and International Relationships." Journal of Communication, 16 (March, 1966), pp. 288-289.

Funnye, C. E. "The Militant Black Social Worker and the Urban Hustle." Soctal Work, 15 (2) 1970, pp. 5-12.

Garcia, Alejandro. "The Chicano and Social Work." Soclal Casework, Vol. 52 \#5, pp. 274-278.

Gardner, G. H. "Cross-Cultural Communication." The Journal of Social Psychology, 1962, 58, pp. 241-256:

Glasgow, Douglas. "The Black Thrust for Vitality: The Impact on Social Work Education." Journal of Education for Soclal Work, Vol. 7 No. 2 (Spring, 1971), pp. 9-18.

Gitterman, Alex and Alice Schaeffer. "The White Professional and the Black Client." Soclal Casework, Vol. 53, No. 5 (May, 1972), pp. 280-291.

Gockros, J. "Recognition and Use of Anger in Negro Clients." Soclal Work, 11 (1) 1966, pp. 28-34.

Goldstein, Rhoda L. Black Life and Culture in the United States. N.Y.: Thomas Y. Crowell Co. 1971.

Harding, Talbot. "Diagnosis and Treatment of Communication Failure." Social Casework, Vol. 49, No. 2, Feb. 1971, pp. 86-90.

Hurst, Charles H. "The Time of Crisis - A Challenge for Social Work Education Everywhere." Education for Social Work, Spring, 1971, pp. 19-24. 
Kadushin, Alfred. "The Racial Factor in the Interview." Social Work, Vol. 17, No. 3 (May, 1972), pp. 88-98.

Rahn, Robert and Charles F. Cannell. The Dynamics of Interviewing. New York, John Wiley and Sons 1957.

Kno11, F. R. "Casework Services for Mexican Americans." Social Casework, 52 (5) (May, 1971), Pp. 279-284.

Knowles, Malcolm S. "Innovation and Teaching Styles and Approaches Based on Adult Learning." Journal of Soclal Work Education C.S.W.E. Vo1. 8, No. 2 (Spring, 1972), pp. 32-39.

Kochman, Thomas. "Rapping in the Black Ghetto." Transaction, Vo1. 6 No. 4 (Feb., 1969), pp. 26-34.

Kochman, Thomas. "Toward an Ethnography of Black American Speech Behavior." in Afro-American Anthropology: Contemporary Perspectives. Norman E. Whitten, Jr. and John F. Szwed Eds. The Free Press, N.Y. 1970, Division of the MacMillan Co. Pp. 145-162.

Kluckhohn, Florence. "Cultural Factors in Soclal Work Practice and Education." Social Service Review, Vol. 25 (March, 1951), pp. 38-47.

Konapke, Gisele. Social Group Work: A Delping Process. New Jersey: Prentice Hall 1963.

Kurowkawa, Minako. "Mutual Perceptions of Raclal Images: White, Black and Japanese Americans." Journal of Soclal Issues, Vol. 27 No. 4 1971, pp. 213-235.

Landy, David. "Prollems of the Person Seeking Help In our Culture." from: Soclal Welfare Institutions, Mayer N. Zald Ed. John Wiley and Sons, Inc. N.Y. 1965.

Lide, Pauline. "Dlalogue on Racism, a Prologue to Action?" Social Casework, Vo1. 52, No. 7 (July, 1971), Pp. 432-437.

Longres, John. "The Impact of Racism on Soclal Work Education." Education for Social Work, Vol. 8 No. 1 (Winter, 1972), pp. 31-41.

Marden, Charles F. and Gladys Meyer. Minorities in American Society. 2nd edition. N.Y.: American Book Co. 1962.

Mehrablan, Albert and Henry Reed. "Some Determinants of Communication Accuracy." Psychological Bulletin, Vol. 70 No. 5 (Nov. 1968), pp. 365-381.

Miller, Roger. "Student Research Perspectives on Race." Smith College Studies in Soclal Work, Vol. 41 No. 1 (Nov. 1970) pp. 1-23. 
Mizio, Emelicia. "White Worker - Minority Client." Soclal Work, Vol. 17 No. 3 (May, 1972), pp. 82-86.

Moore, Joan W. Mexican Americans. Englewood Cliffs, New Jersey Prentice Hall Inc. 1970.

Morales, Armando. "The Collective Preconsclous and Racism." Soctal Casework, 52 (5) 1971, pp. 285-293.

Mullen, Edward J. "Casework Communication." Social Casework, Vol. XLIX No. 8 (Octo. 1968), pp. 546-551.

McGrath, Earl Jones. Communication in General Education. Dubuque: Wh. C. Brown Co. 1949.

01ds, Victoria M. "Sit-Ins: Social Action to End Segregation." Soclal Work, Vo1. 6 No. 32 (April, 1961) pp. 99-105.

O'Reilly, C. T. "Race in Social Welfare Race, Research and Reason." Soclal Work Perspectives (NASW) 1969, Pp. 89-97.

Penalosa, Fernando. "Recent Changes Among the Chicanos." Soctology and Social Research, (Oct. 1970) pp. 47-52.

Penalosa, Fernando. "Mexican Family Roles." Marriage and the Family, Vol. 30 (Nov. 1968), pp. 680-688. Xeroxed.

Petro, 0live and Betty French. "The Black Client's View of Himself." Social Casework, Vol. 53 非 (Oct. 1972), pp. 466-474.

Ramsey, Glenn V. and Beulah Hodge. "Anglo-Latin Problems as Perceived by Public Service Personnel." Social Forces, Vol. 37 \#4 (May, 1959), pp. 339-348.

Reeves, Gloria D. "Preconditioned Panic Responses to Black Militancy." Social Casework, Vol. 52 No. 1 (Jan. 1971), pp. 26-31.

Richardson, Stephen A., Barbara Snell Dohremwend and David Kleen. Interviering, its Forms and Functions. Basic Books, Inc. N.Y. 1965.

Rose, Arnold and Caroline. America Divided: Minority Group Relations In the United State. Alfred A. Knopf. NY: 1950.

Rosenfelt, Jona Michael. "Strangeness Between Helper and Client: A Possible Explanation of Non-Use of Available Professional Help." Soctal Service Review, $38: 19$ (March, 1964).

Rowan, Helen. "A Minority Nobody Knows." The Atlantic Monthly,No. 219 June, 1967, pp. 47-52. Xeroxed. 
Saunders, M. S. "The Ghetto: Some Perceptions of a Black Social Worker." Social Work, 14 (4) 1969, pp. 84-88.

Schubert, Margaret. Interviewing in Social Work Practice. Council on Social Work Education. N.Y. N.Y. 1971.

Schuman, Howard. "Soclological Racism." Trans-Action, 7 (2) 199, pp. 44-48.

Schuman, Howard and Jean M. Converse. "The Effects of Black and White Interviewers on Black Responses in 1968." Public Opinion Quarterly, Vol. 35 No. 1 (Spring, 1971), pp. 44-68.

Seligman, Michele. "The Interracial Casework Relationship." Smith College Studies in Social Work, Vol. 39 No. 1 (nov. 1968), p. 84 .

Shannon, Barbara E. "Implications of White Racism for Social Work Practice." Soclal Casework, (May, 1970), Vol. 51 No. 5 pp. 270-276.

Silverman, P. R. A. "A Re-Examination of the Intake Procedure." Soclal Casework, 51 (10) 1970, pp. 625-634.

Silverman, P. R. "The Influence of Racial Differences on the Negro Patient Dropping Out of Psychlatric Treatment." Psychiatric Opinion, 8 (1) 1971, pp. 29-36.

Simmons, Leonard C. "Crow Jim: Implications for Social Work." Soclal Work, Vol. 8 No. 3 (July, 1963), pp. 24-30.

Smith, Alfred G. Communication and Culture. N.Y.: 1966 Holt, Rinehart and Winston. 1966.

Solis, Faustina. "Socioeconomic and Cultural Conditions of Migrant Workers." Social Casework, (May, 1971), pp. 308-315.

Sotomayor, Marta. "Mexican-American Interaction with Soclal Systems." Soctal Casework, (May, 1971), pp. 316-322.

Sponjer, R. Allan. "Communication Skills." Adopted from Lectures by John Wallen at the Clinical Supervision Institute, Portland State Univesity, Portland, Oregon 1965.

Stein, Herman and Risland A. Cloward. Social Perspectives on Behavior. N.Y.: Free Press 1958 - Forward by Gordon Hamilton, p. 11.

Stiles, Evelyn et al. "Hear It Like It Is." Soclal Casework, Vol. 53 No. 5 (May, 1972), pp. 292-299.

St. Julien, Maye Johnson. The Influence of Ethnicity on the Casework Relationship: A Review of Literature. Thesis for Partial Fulfillment of M.S.W. Our Lady of the Lake College, San Antonio, Texas (May, 1969). Unpublished. 
Taylor, Donald M. and Robert C. Gardner. "Ethnic Stereotypes: Their Effects on the Perception of Communicators of Varying Credibility." Canadian Journal of Psychology, 1969, 23 (3) pp. 161-173. Xeroxed.

Taylor, Ronald and Lise M. Simard. "The Role of Bilingualism in Cross-Cultural Communication." Journal of Cultura1 Psychology, Vo1. 3 No. 1 March, 1972.

Tidwell, Billy. "The Black Community's Challenge to Social Work." Education for Social Work, Fall, 1971, pp. 59-65.

Turner, John B. "Education for Practice with Minorities." Social Work, Vol. 17 No. 3 (May, 1972), pp. 112-118.

U. S. News "Another Civil-Rights Headache, Plight of Mexican Americans." Vol. 60 June 6, 1966, pp. 46-48.

Vail, S. "The Effects of Socio-Economic Class, Race and Levels of Experience on Social Workers Judgments of Clients." Smith College Studies in Social Work 40 (3) 1970, pp. 234-46.

Vontross, C. "Counseling Blacks." Personnel and Guidance Journal, Vo1. 48 No. 9 (May, 1970), 713-719.

Vontross, C. "Racial Differences - Impediments to Rapport." Journal of Counseling Psychology, Vol. 18 No. 1 (January, 1971), pp. 7-13.

Vontross, C. "Cultural Barriers in Counseling Relationships." Personnel and Guidance Journal, Vol. 48 No. 1 (Sept. 1969) pp. 11-16.

Wedge, Bryant. "Toward a Science of Transnational Communication." Group for the Advancement of Prychiatry. Report No. 41, Symposium No. 7, Vol IV, Part 1. New York, December 1959, pp. 383-394.

Weiner, Margaret. "Gentlemen's Agreement Revisited." Soclal Casework, 51 (July, 1970), pp. 395-398.

Wyer, Robert S., Jr. and Sandra Schwartz. "Source Effects on the Evaluation of Communication." Journal of Personality and Social Psychology, 1969 Vol. 11 No. 1, Pp. 1-9.

Yancy, William and Boone Hammond. "Glossary of Negro Jive." St. Louis: Washington University, Social Science Institute 1965. Mimeographed. 